\title{
Editorial
}

\section{Welcome to Seminars in Thrombosis \& Hemostasis 2016: New (2014) Impact Factor and Most Highly Cited Articles}

\author{
Emmanuel J. Favaloro, PhD, FFSc (RCPA) ${ }^{1}$ \\ ${ }^{1}$ Department of Haematology, Institute of Clinical Pathology and \\ Medical Research (ICPMR), Westmead Hospital, Westmead, Australia
}

Semin Thromb Hemost 2016;42:1-4.

Welcome to the start of yet another year with Seminars in Thrombosis \& Hemostasis (STH). This is my 8th year as the Editor-in-Chief, and my 11th year of editorial association with this journal, having originally served as a Regional Editor. First, I sincerely wish to thank all the contributors to STH over the past years, as well as the Guest Editors for these issues, and of course the current and past Senior and Associate Editors of the journal. There have been several changes to the editorial team. We have two new Senior Editors: Ton Lisman joins Marcel Levi as a second European Senior Editor, and Sam Schulman, a long-time Associate Editor of STH, joins Hau Kwaan as a second North American Senior Editor. We have also increased the ranks of Associate Editors, with the aim to have around 10 to 12 contributing issues from each of the "global regions" of America, Europe, and Asia-Pacific.

I will also take this opportunity to thank the journal production team at Thieme Medical Publishers for their high production standards and for facilitating both the print and online issues of the journal. In particular, I would like to thank Subhankar De, the Production Editor for STH who now leads the production team. I also wish to thank Kelly Coffey, a Journals Coordinator for Thieme Medical Publishers, as well as other key people at Thieme, some of whom prefer to remain unnamed, for the additional support provided over recent years.

This is also the time that we reflect on our journal's impact factor, which for 2014 was 3.876, which represents a small rise from our 2013 impact factor of 3.693 (-Fig. 1). I am hopeful that this reflects a stabilization of the STH impact factor at around 4 over the coming years. In any case, the impact factor is not the only marker of journal "quality" that we should consider, given the existence of other biometric markers and the limitations of any individual marker (including the impact factor) as a "quality" indicator. ${ }^{1,2}$

As I also now do annually, the highest cited (2012/2013published) contributions ${ }^{3-43}$ from this journal are listed

in -Table 1 for the potential interest of the readership and contributing authors. These contributions identify those publications, most contributing to the 2014 impact factor, and each have now been cited 15 or more times in literature, with the top 11-listed articles having been cited 25 or more times. For those interested, the current listing can be compared with those of the most recently published top downloaded article listings from STH, the basis of the Eberhard F. Mammen "most popular" awards. ${ }^{44,45}$ Accordingly, I would like to thank all the contributors, guest editors, and the editorial team for bringing us the content that makes STH.

Finally, a short note to confirm that, as always, we will continue to develop plans for the future content of this journal, and we are confident that we will be able to continue to bring its readers the high-quality journal that is expected from us. Currently confirmed topics for issues that we plan to publish over the next 12 or so months are listed in - Table 2.

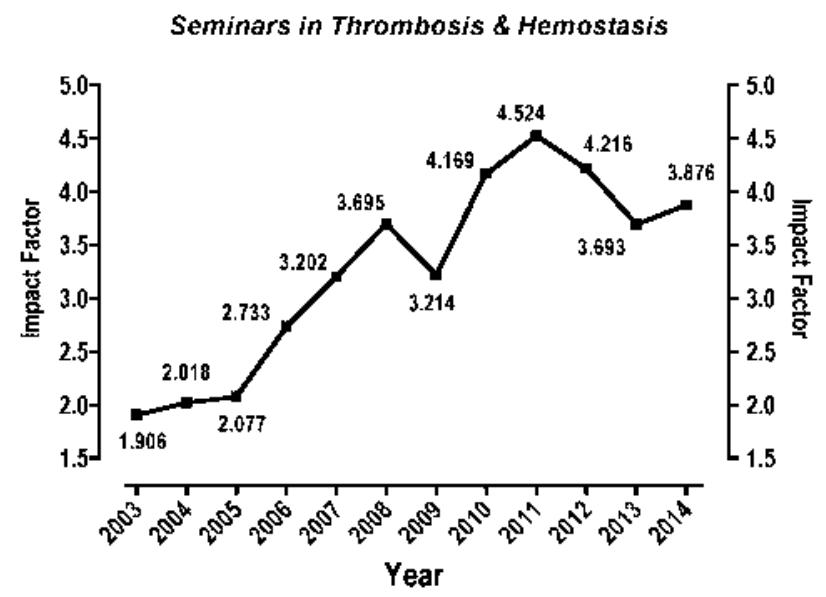

Fig. 1 The impact factor for Seminars in Thrombosis \& Hemostasis, from 2003 to 2014.

Copyright @ 2016 by Thieme Medical Publishers, Inc., 333 Seventh Avenue, New York, NY 10001, USA. Tel: +1(212) 584-4662.
DOI http://dx.doi.org/ $10.1055 / \mathrm{s}-0035-1568874$. ISSN 0094-6176.
Department of Haematology, $\quad$ Emmanuel J. Favaloro, PhD, FFSc Institute of Clinical Pathology and (RCPA), and Giuseppe Lippi, MD. Medical Research (ICPMR),

Westmead Hospital, Westmead,

NSW 2145, Australia

(e-mail: emmanuel.

favaloro@health.nsw.gov.au). 
Table 1 Most highly cited, 2012/2013 published, contributions from Seminars in Thrombosis \& Hemostasis

\begin{tabular}{|c|}
\hline $\begin{array}{l}1 \text { Lippi G, Salvagno GL, Montagnana M, Lima-Oliveira G, Guidi GC, Favaloro EJ. Quality standards for sample collection in } \\
\text { coagulation testing. Semin Thromb Hemost 2012;38(6):565-575 }\end{array}$ \\
\hline $\begin{array}{l}2 \text { Harenberg J, Giese C, Marx S, Krämer R. Determination of dabigatran in human plasma samples. Semin Thromb Hemost } \\
\text { 2012;38(1):16-22 }\end{array}$ \\
\hline $\begin{array}{l}3 \text { Harenberg J, Erdle S, Marx S, Krämer R. Determination of rivaroxaban in human plasma samples. Semin Thromb Hemost } \\
\text { 2012;38(2):178-184 }\end{array}$ \\
\hline $\begin{array}{l}4 \text { Dentali F, Sironi AP, Ageno W, et al. Non-O blood type is the commonest genetic risk factor for VTE: results from a meta-analysis } \\
\text { of the literature. Semin Thromb Hemost 2012;38(5):535-548 }\end{array}$ \\
\hline 5 Willis R, Harris EN, Pierangeli SS. Pathogenesis of the antiphospholipid syndrome. Semin Thromb Hemost 2012;38(4):305-321 \\
\hline $\begin{array}{l}6 \text { Adcock Funk DM, Lippi G, Favaloro EJ. Quality standards for sample processing, transportation, and storage in hemostasis } \\
\text { testing. Semin Thromb Hemost 2012;38(6):576-585 }\end{array}$ \\
\hline $\begin{array}{l}7 \text { Pengo V, Banzato A, Bison E, Bracco A, Denas G, Ruffatti A. What have we learned about antiphospholipid syndrome from } \\
\text { patients and antiphospholipid carrier cohorts? Semin Thromb Hemost 2012;38(4):322-327 }\end{array}$ \\
\hline $\begin{array}{l}8 \text { Coppola A, Tagliaferri A, Di Capua M, Franchini M. Prophylaxis in children with hemophilia: evidence-based achievements, old } \\
\text { and new challenges. Semin Thromb Hemost 2012;38(1):79-94 }\end{array}$ \\
\hline $\begin{array}{l}9 \text { Aatonen M, Grönholm M, Siljander PR. Platelet-derived microvesicles: multitalented participants in intercellular communi- } \\
\text { cation. Semin Thromb Hemost 2012;38(1):102-113 }\end{array}$ \\
\hline $\begin{array}{l}10 \text { Linden MD, Tran H, Woods R, Tonkin A. High platelet reactivity and antiplatelet therapy resistance. Semin Thromb Hemost. } \\
2012 \text { Mar;38(2):200-12. }\end{array}$ \\
\hline $\begin{array}{l}11 \text { Kershaw G, Suresh S, Orellana D, Nguy YM. Laboratory identification of lupus anticoagulants. Semin Thromb Hemost } 2012 ; 38 \\
\text { (4):375-384 }\end{array}$ \\
\hline $\begin{array}{l}12 \text { Declerck PJ, Gils A. Three decades of research on plasminogen activator inhibitor-1: a multifaceted serpin. Semin Thromb } \\
\text { Hemost 2013;39(4):356-364 }\end{array}$ \\
\hline $\begin{array}{l}13 \text { Lippi G, Plebani M, Favaloro EJ. Interference in coagulation testing: focus on spurious hemolysis, icterus, and lipemia. Semin } \\
\text { Thromb Hemost 2013;39(3):258-266 }\end{array}$ \\
\hline 14 Levi M, Schultz M, van der Poll T. Sepsis and thrombosis. Semin Thromb Hemost 2013;39(5):559-566 \\
\hline $\begin{array}{l}15 \text { Bates SM. D-dimer assays in diagnosis and management of thrombotic and bleeding disorders. Semin Thromb Hemost } \\
\text { 2012;38(7):673-682 }\end{array}$ \\
\hline $\begin{array}{l}16 \text { Plebani M, Favaloro EJ, Lippi G. Patient safety and quality in laboratory and hemostasis testing: a renewed loop? Semin Thromb } \\
\text { Hemost 2012;38(6):553-558 }\end{array}$ \\
\hline $\begin{array}{l}17 \text { Favaloro EJ, Bonar R, Marsden K. Internal quality control and external quality assurance in testing for antiphospholipid } \\
\text { antibodies: Part II-Lupus anticoagulant. Semin Thromb Hemost 2012;38(4):404-411 }\end{array}$ \\
\hline $\begin{array}{l}18 \text { Sørensen B, Larsen OH, Rea CJ, Tang M, Foley JH, Fenger-Eriksen C. Fibrinogen as a hemostatic agent. Semin Thromb Hemost } \\
\text { 2012;38(3):268-273 }\end{array}$ \\
\hline $\begin{array}{l}19 \text { Franchini M, Coppola A, Rocino A, et al; Italian Association of Hemophilia Centers (AICE) Working Group. Systematic review of } \\
\text { the role of FVIII concentrates in inhibitor development in previously untreated patients with severe hemophilia a: a } 2013 \\
\text { update. Semin Thromb Hemost 2013;39(7):752-766 }\end{array}$ \\
\hline $\begin{array}{l}20 \text { Favaloro EJ, Wheatland L, Jovanovich S, Roberts-Thomson P, Wong RC. Internal quality control and external quality assurance } \\
\text { in testing for antiphospholipid antibodies: Part I-Anticardiolipin and anti- } \beta 2 \text {-glycoprotein I antibodies. Semin Thromb } \\
\text { Hemost 2012;38(4):390-403 }\end{array}$ \\
\hline
\end{tabular}

21 Stasi R. Immune thrombocytopenia: pathophysiologic and clinical update. Semin Thromb Hemost 2012;38(5):454-462

22 Harenberg J, Du S, Krämer S, et al. Novel methods for assessing oral direct factor Xa and thrombin inhibitors: use of point-of-care testing and urine samples. Semin Thromb Hemost 2013;39(1):66-71

23 Tufano A, Di Capua M, Coppola A, et al. The infectious burden in atherothrombosis. Semin Thromb Hemost 2012;38(5):515-523

24 Tripodi A. To mix or not to mix in lupus anticoagulant testing? That is the question. Semin Thromb Hemost 2012;38(4):385-389

25 Chapman K, Seldon M, Richards R. Thrombotic microangiopathies, thrombotic thrombocytopenic purpura, and ADAMTS-13. Semin Thromb Hemost 2012;38(1):47-54

26 Salmela B, Joutsi-Korhonen L, Armstrong E, Lassila R. Active online assessment of patients using new oral anticoagulants: bleeding risk, compliance, and coagulation analysis. Semin Thromb Hemost 2012;38(1):23-30

27 Franchini M, Lippi G, Favaloro El. Acquired inhibitors of coagulation factors: part II. Semin Thromb Hemost 2012;38(5):447-453 
Table 1 (Continued)

28 Targher G, Pichiri I, Lippi G. Vitamin D, thrombosis, and hemostasis: more than skin deep. Semin Thromb Hemost 2012;38(1):114-124

29 Favaloro EJ, Plebani M, Lippi G. Regulation in hemostasis and thrombosis: part I-in vitro diagnostics. Semin Thromb Hemost 2013;39(3):235-249

30 Turner N, Nolasco L, Moake J. Generation and breakdown of soluble ultralarge von Willebrand factor multimers. Semin Thromb Hemost 2012;38(1):38-46

31 Duga S, Salomon O. Congenital factor XI deficiency: an update. Semin Thromb Hemost 2013;39(6):621-631

32 Targher G, Byrne CD. Diagnosis and management of nonalcoholic fatty liver disease and its hemostatic/thrombotic and vascular complications. Semin Thromb Hemost 2013;39(2):214-228

33 Hayward CP, Moffat KA, Liu Y. Laboratory investigations for bleeding disorders. Semin Thromb Hemost 2012;38(7):742-752

34 Cervera R, Espinosa G. Update on the catastrophic antiphospholipid syndrome and the "CAPS Registry". Semin Thromb Hemost 2012;38(4):333-338

35 Kwaan HC, Mazar AP, McMahon BJ. The apparent uPA/PAI-1 paradox in cancer: more than meets the eye. Semin Thromb Hemost 2013;39(4):382-391

36 Levi M, van der Poll T, Schultz M. Infection and inflammation as risk factors for thrombosis and atherosclerosis. Semin Thromb Hemost 2012;38(5):506-514

37 Franchini M, Mannucci PM. Thrombin and cancer: from molecular basis to therapeutic implications. Semin Thromb Hemost 2012;38(1):95-101

38 Di Minno MN, lervolino S, Lupoli R, et al. Cardiovascular risk in rheumatic patients: the link between inflammation and atherothrombosis. Semin Thromb Hemost 2012;38(5):497-505

39 Prechel M, Walenga JM. Heparin-induced thrombocytopenia: an update. Semin Thromb Hemost 2012;38(5):483-496

40 Willis R, Harris EN, Pierangeli SS. Current international initiatives in antiphospholipid antibody testing. Semin Thromb Hemost 2012;38(4):360-374

Table 2 The current planned topics for future issues of Seminars in Thrombosis \& Hemostasis include

- Editorial compilations (continuing series)

- At the crossroads of transfusion medicine and hemostasis

- Platelet function in thrombosis and hemostasis

- Controversies in inherited bleeding disorders

- The role of fibrinogen and factor XIII in hemostasis, and the identification and treatment of associated disorders

- Thrombosis \& hemostasis in women and during pregnancy

- Laboratory assessment and monitoring of therapy in thrombosis and bleeding disorders

- Fibrinolysis

- Antiphospholipid antibodies and the antiphospholipid syndrome

At the same time, we recognize the need to retain some flexibility in our plans, and to potentially add additional material of current interest and controversy as the need arises. We look forward to another interesting year of reading in 2016.

\section{References}

1 Favaloro EJ. The journal impact factor: don't expect its demise any time soon. Clin Chem Lab Med 2009;47(11):1319-1324

2 Favaloro EJ. Measuring the quality of journals and journal articles: the impact factor tells but a portion of the story. Semin Thromb Hemost 2008;34(1):7-25
3 Lippi G, Salvagno GL, Montagnana M, Lima-Oliveira G, Guidi GC, Favaloro EJ. Quality standards for sample collection in coagulation testing. Semin Thromb Hemost 2012;38(6):565-575

4 Harenberg J, Giese C, Marx S, Krämer R. Determination of dabigatran in human plasma samples. Semin Thromb Hemost 2012; 38(1):16-22

5 Harenberg J, Erdle S, Marx S, Krämer R. Determination of rivaroxaban in human plasma samples. Semin Thromb Hemost 2012; 38(2):178-184

6 Dentali F, Sironi AP, Ageno W, et al. Non-O blood type is the commonest genetic risk factor for VTE: results from a metaanalysis of the literature. Semin Thromb Hemost 2012;38(5): 535-548

7 Willis R, Harris EN, Pierangeli SS. Pathogenesis of the antiphospholipid syndrome. Semin Thromb Hemost 2012;38(4):305-321 
8 Adcock Funk DM, Lippi G, Favaloro EJ. Quality standards for sample processing, transportation, and storage in hemostasis testing. Semin Thromb Hemost 2012;38(6):576-585

9 Pengo V, Banzato A, Bison E, Bracco A, Denas G, Ruffatti A. What have we learned about antiphospholipid syndrome from patients and antiphospholipid carrier cohorts? Semin Thromb Hemost 2012;38(4):322-327

10 Coppola A, Tagliaferri A, Di Capua M, Franchini M. Prophylaxis in children with hemophilia: evidence-based achievements, old and new challenges. Semin Thromb Hemost 2012;38(1):79-94

11 Aatonen M, Grönholm M, Siljander PR. Platelet-derived microvesicles: multitalented participants in intercellular communication. Semin Thromb Hemost 2012;38(1):102-113

12 Linden MD, Tran H, Woods R, Tonkin A. High platelet reactivity and antiplatelet therapy resistance. Semin Thromb Hemost 2012; 38(2):200-212

13 Coppola A, Favaloro EJ, Tufano A, Di Minno MN, Cerbone AM, Franchini M. Acquired inhibitors of coagulation factors: part Iacquired hemophilia A. Semin Thromb Hemost 2012;38(5):433-446

14 Kershaw G, Suresh S, Orellana D, Nguy YM. Laboratory identification of lupus anticoagulants. Semin Thromb Hemost 2012;38(4): 375-384

15 Declerck PJ, Gils A. Three decades of research on plasminogen activator inhibitor-1: a multifaceted serpin. Semin Thromb Hemost 2013;39(4):356-364

16 Lippi G, Plebani M, Favaloro EJ. Interference in coagulation testing: focus on spurious hemolysis, icterus, and lipemia. Semin Thromb Hemost 2013;39(3):258-266

17 Levi M, Schultz M, van der Poll T. Sepsis and thrombosis. Semin Thromb Hemost 2013;39(5):559-566

18 Bates SM. D-dimer assays in diagnosis and management of thrombotic and bleeding disorders. Semin Thromb Hemost 2012;38(7): 673-682

19 Plebani M, Favaloro EJ, Lippi G. Patient safety and quality in laboratory and hemostasis testing: a renewed loop? Semin Thromb Hemost 2012;38(6):553-558

20 Favaloro EJ, Bonar R, Marsden K. Internal quality control and external quality assurance in testing for antiphospholipid antibodies: Part II-Lupus anticoagulant. Semin Thromb Hemost 2012; 38(4):404-411

21 Sørensen B, Larsen OH, Rea CJ, Tang M, Foley JH, Fenger-Eriksen C. Fibrinogen as a hemostatic agent. Semin Thromb Hemost 2012; 38(3):268-273

22 Franchini M, Coppola A, Rocino A, et al; Italian Association of Hemophilia Centers (AICE) Working Group. Systematic review of the role of FVIII concentrates in inhibitor development in previously untreated patients with severe hemophilia a: a 2013 update. Semin Thromb Hemost 2013;39(7):752-766

23 Favaloro EJ, Wheatland L, Jovanovich S, Roberts-Thomson P, Wong RC. Internal quality control and external quality assurance in testing for antiphospholipid antibodies: Part I-Anticardiolipin and anti-B2-glycoprotein I antibodies. Semin Thromb Hemost 2012;38(4):390-403

24 Stasi R. Immune thrombocytopenia: pathophysiologic and clinical update. Semin Thromb Hemost 2012;38(5):454-462

25 Harenberg J, Du S, Krämer S, et al. Novel methods for assessing oral direct factor Xa and thrombin inhibitors: use of point-of-care testing and urine samples. Semin Thromb Hemost 2013;39(1): 66-71

26 Tufano A, Di Capua M, Coppola A, et al. The infectious burden in atherothrombosis. Semin Thromb Hemost 2012;38(5):515-523

27 Tripodi A. To mix or not to mix in lupus anticoagulant testing? That is the question. Semin Thromb Hemost 2012;38(4):385-389

28 Chapman K, Seldon M, Richards R. Thrombotic microangiopathies, thrombotic thrombocytopenic purpura, and ADAMTS-13. Semin Thromb Hemost 2012;38(1):47-54

29 Salmela B, Joutsi-Korhonen L, Armstrong E, Lassila R. Active online assessment of patients using new oral anticoagulants: bleeding risk, compliance, and coagulation analysis. Semin Thromb Hemost 2012;38(1):23-30

30 Franchini M, Lippi G, Favaloro EJ. Acquired inhibitors of coagulation factors: part II. Semin Thromb Hemost 2012;38(5):447-453

31 Targher G, Pichiri I, Lippi G. Vitamin D, thrombosis, and hemostasis: more than skin deep. Semin Thromb Hemost 2012;38(1): 114-124

32 Favaloro EJ, Plebani M, Lippi G. Regulation in hemostasis and thrombosis: part I-in vitro diagnostics. Semin Thromb Hemost 2013;39(3):235-249

33 Turner N, Nolasco L, Moake J. Generation and breakdown of soluble ultralarge von Willebrand factor multimers. Semin Thromb Hemost 2012;38(1):38-46

34 Duga S, Salomon O. Congenital factor XI deficiency: an update. Semin Thromb Hemost 2013;39(6):621-631

35 Targher G, Byrne CD. Diagnosis and management of nonalcoholic fatty liver disease and its hemostatic/thrombotic and vascular complications. Semin Thromb Hemost 2013;39(2):214-228

36 Hayward CP, Moffat KA, Liu Y. Laboratory investigations for bleeding disorders. Semin Thromb Hemost 2012;38(7):742-752

37 Cervera R, Espinosa G. Update on the catastrophic antiphospholipid syndrome and the "CAPS Registry". Semin Thromb Hemost 2012;38(4):333-338

38 Kwaan HC, Mazar AP, McMahon BJ. The apparent uPA/PAI-1 paradox in cancer: more than meets the eye. Semin Thromb Hemost 2013;39(4):382-391

39 Levi M, van der Poll T, Schultz M. Infection and inflammation as risk factors for thrombosis and atherosclerosis. Semin Thromb Hemost 2012;38(5):506-514

40 Franchini M, Mannucci PM. Thrombin and cancer: from molecular basis to therapeutic implications. Semin Thromb Hemost 2012; 38(1):95-101

41 Di Minno MN, Iervolino S, Lupoli R, et al. Cardiovascular risk in rheumatic patients: the link between inflammation and atherothrombosis. Semin Thromb Hemost 2012;38(5):497-505

42 Prechel M, Walenga JM. Heparin-induced thrombocytopenia: an update. Semin Thromb Hemost 2012;38(5):483-496

43 Willis R, Harris EN, Pierangeli SS. Current international initiatives in antiphospholipid antibody testing. Semin Thromb Hemost 2012;38(4):360-374

44 Favaloro EJ. 2014 Eberhard F. Mammen Award announcements: Part I-Most popular articles. Semin Thromb Hemost 2014;40(4): 407-412

45 Favaloro EJ. 2015 Eberhard F. Mammen Award Announcements: Part I-Most Popular Articles. Semin Thromb Hemost 2015;41(7): 673-679 